\title{
Etnomatematika Tradisi Meron di Sukolilo dan Kaitannya dengan Pembelajaran Geometri
}

\author{
Asyrifah Zaini Wahda ${ }^{1}$, Arghob Khofya Haqiqi, Putri Nur Malasari \\ ${ }^{1}$ Institut Agama Islam Negeri Kudus \\ 1asyrifahzaini00@gmail.com
}

\begin{tabular}{l}
\hline \hline Article Info \\
\hline Article history: \\
Received April 10 $0^{\text {th }}, 2021$ \\
Revised June $03^{\text {rd }}, 2021$ \\
Accepted June $10^{\text {th }}, 2021$ \\
\hline
\end{tabular}

Keywords:

Ethnomathematics; Geometry;

Meron
As an effort to assist in improving the quality of education, mathematics is taught to students in formal educational institutions from the basic level of education. However, many students do not like mathematics and consider it the most difficult subject. To address this, teachers can apply ethnomathematics learning to learning activities. One of the cultures that can be used is the meron tradition. The meron tradition is one of the traditions of Islamic ritual ceremonies in Sukolilo which is intended as an event to commemorate the birthday of the Prophet Muhammad. The purpose of this study is to examine the existence of ethnomathematics in the meron tradition in Sukolilo, on the topic of geometry in learning mathematics. This research was conducted using qualitative research with an ethnographic approach. The research data collection techniques about the meron tradition, using interview techniques, and documentation with research instruments include interview guidelines and field notes. Interviews were conducted with five residents of Sukolilo. Data analysis used descriptive qualitative method. The results showed that the concept of ethnomathematics in the meron tradition can be seen in each part of the meron. In the mustaka section there is a wreath in the form of a flat circular shape and in the miniature form of the mosque there is a rectangular shape of a cube and pyramid, the gunungan section has a cone shape, the ancak section has two flat shapes, namely a rectangle and a trapezoid.

Kata Kunci:

Etnomatematika;

Geometri;

Meron

\section{Abstrak}

Sebagai upaya bantuan dalam meningkatkan mutu pendidikan, matematika diajarkan kepada peserta didik di lembaga pendidikan formal sejak jenjang pendidikan dasar. Namun banyak siswa yang tidak suka dengan 
matematika dan menganggapnya pelajaran paling sulit. Untuk menyikapi hal tersebut guru dapat menerapkan pembelajaran etnomatematika pada kegiatan pembelajaran. Salah satu budaya yang dapat digunakan yaitu tradisi meron. Tradisi meron merupakan salah satu tradisi upacara ritual islam di Sukolilo yang ditujukan sebagai acara peringatan hari kelahiran Nabi Muhammad SAW. Tujuan penelitian ini adalah mengkaji adanya etnomatematika pada tradisi meron di Sukolilo, pada topik geometri dalam pembelajaran matematika. Penelitian ini dilakukan menggunakan penelitian kualitatif dengan pendekatan etnografi. Adapun teknik pengumpulan data penelitian tentang tradisi meron, menggunakan teknik wawancara, dan dokumentasi dengan instrumen penelitian meliputi pedoman wawancara dan catatan lapangan. Wawancara dilakukan kepada lima warga Sukolilo. Analisis data menggunakan metode deskriptif kualitatif. Hasil penelitian menunjukkan bahwa konsep etnomatematika pada tradisi meron dapat dilihat pada masing-masing bagian meron. Pada bagian mustaka terdapat karangan bunga yang berbentuk bangun datar lingkaran dan pada bentuk miniatur masjid terdapat bentuk kubus dan limas segiempat, bagian gunungan terdapat bentuk kerucut, bagian ancak terdapat dua bangun datar yaitu persegi panjang dan trapesium.

\section{PENDAHULUAN}

Matematika merupakan salah satu ilmu dasar yang bercirikan objeknya yang abstrak dan berpola pikir deduktif. Sebagai upaya bantuan dalam meningkatkan mutu pendidikan, matematika diajarkan kepada peserta didik sejak berada di jenjang SD (Sekolah Dasar). Intinya pembelajaran matematika ini dilakukan untuk mendukung siswa dalam menyelesaikan permasalahan dengan pola pikir yang kritis, logis, tepat dan cermat (Makhmudah, 2018).

Pembelajaran matematika di sekolah memiliki beberapa cabang ilmu seperti kalkulus, aritmatika, statistika, geometri dan aljabar. Dalam kurikulum matematika, geometri menempati posisi penting yang mengharuskan untuk diajarkan kepada siswa sejak di jenjang pendidikan dasar hingga perguruan tinggi. Menurut Walle (Rahimah \& Asy'ari, 
2017) menyatakan bahwa alasan perlunya mempelajari geometri adalah (1) geometri memiliki peran utama dalam bidang matematika lainnya; (2) siswa dapat mengeksplorasi geometri sebagai upaya dalam mengembangkan kemampuan pemecahan suatu permasalahan; (3) geometri juga banyak diaplikasikan dalam perilaku keseharian di lingkungan masyarakat yang penuh dengan tantangan yang menarik untuk diselesaikan.

Banyak siswa yang tidak suka dengan matematika dan menganggapnya pelajaran paling sulit. Sehingga hal tersebut berpengaruh terhadap hasil belajar matematika. Hal ini dapat dilihat berdasarkan hasil survei oleh PISA (Programme for International Student Assessment) tahun 2018 (OECD, 2019), Indonesia memperoleh rangking 72 dari 78 negara, dan memperoleh skor 379 dengan predikat ketujuh dari bawah dalam kategori nilai. Dari hasil tersebut dapat dikatakan bahwa kemampuan matematis siswa tergolong rendah jika dibandingkan dengan negara-negara lainnya.

PISA diadakan selama tiga tahun sekali sebagai tolak ukur kecerdasan anak usia 15 tahun di seluruh dunia. PISA digunakan untuk menilai sejauh mana pengetahuan dan keterampilan yang dimiliki peserta didik, dimana penilaiannya terfokus pada kemahiran dalam membaca, matematika, sains, kesejahteraan siswa dan domain inovatif yang berupa kompetensi global (Crato, 2020).

Matematika adalah ilmu yang bersifat abstrak, sehingga banyak peserta didik yang merasa kesulitan untuk memahaminya (Prasetyawan, 2016). Apalagi dengan metode pembelajaran yang diterapkan guru cenderung monoton, dimana siswa hanya belajar secara prosedural terkait dengan konsep dan rumus matematika saja. Sejalan dengan Auliya (2019) penggunaan metode yang kurang tepat dapat menyebabkan siswa kurang mampu atau kesulitan dalam menggunakan pengetahuan matematika yang dimilikinya dalam menyelesaikan masalah sehari-hari yang berkaitan dengan matematika.

Berdasarkan kurikulum 2013, guru harus bisa menghadirkan pembelajaran yang kreatif, inovatif, dan kolaboratif. Dalam kegiatan belajar mengajar guru dituntut untuk dapat memperkenalkan pendidikan 
yang lebih bermanfaat bagi lingkungan sekitar. Guru dapat menggunakan metode pembelajaran yang memanfaatkan kebudayaan di sekitar dalam proses penyampaian materi. Dalam membantu siswa untuk meningkatkan pemahaman matematika, guru dapat membantu siswa dengan menghadirkan sumber belajar matematika yang berkaitan dengan kehidupan nyata, seperti mengajak siswa untuk mengamati benda-benda di sekitar dan mengaitkannya dalam pembelajaran matematika. Dalam proses pembelajaran, guru dapat mengajak siswa mengamati kebudayaan yang ada di sekitar. Pendidikan dan budaya merupakan suatu kesatuan utuh dalam masyarakat yang merupakan suatu kolaborasi atau perpaduan yang mendasar dan tak terhindarkan oleh setiap orang dalam kehidupan sehari-hari, termasuk dalam hal pembelajaran matematika.(Nur, Hobri, \& Dian, 2015).

Etnomatematika berasal dari kata ethno, mathema, dan tics. Kata ethno diartikan sebagai sesuatu yang sangat luas yang berhubungan pada sosial budaya. sedangkan kata mathema berarti menunjukkan, mengerti, memahami, dan melaksanakan kegiatan seperti pengkodean, pengukuran, pengklasifikasian, penyimpulan, dan pemodelan, dan kata tics berarti teknik. Sehingga diperoleh kesimpulan bahwa arti etnomatematika secara etimologi didefinisikan sebagai antropologi budaya matematika dan pendidikan matematika (D'Ambrosio, 1985). Etnomatematika juga merupakan salah satu hal yang menjembatani antara budaya dan pendidikan khususnya pada pelajaran matematika (Wahyuni, Aji, Tias, \& Sani, 2013).

Salah satu kebudayaan yang dapat dijadikan objek matematika adalah tradisi meron di Sukolilo. Tradisi meron merupakan salah satu tradisi upacara ritual Islam di Sukolilo yang ditujukan sebagai acara peringatan hari kelahiran Nabi Muhammad SAW. Tradisi ini merupakan salah satu bentuk tradisi unik yang diadakan setiap tahunnya. Disebut unik karena tradisi meron ini mengandung kegiatan serimonial yang memiliki kekuatan magis religius. Tradisi meron ini mirip dengan tradisi grebeg maulid (sekaten) yang diadakan di Keraton Yogyakarta maupun Keraton Surakarta. 
Meron berasal dari bahasa Jawa rame (keramaian) dan tiron (meniru). Sedangkan dalam bahasa Arab meron berasal dari kata mi'raj yang berarti kemenangan (Fahrida, 2012). Pengimplementasian pada pembelajaran geometri dapat dilakukan guru dengan mengajak siswa untuk mengeksplorasi dan mempelajari berbagai jenis geometri yang ada pada tradisi meron tersebut, seperti bangun datar, bangun ruang, dan menghitung luas dari bangun-bangun tersebut. Dengan penggunaan tradisi meron dalam pembelajaran matematika diharapkan dapat memotivasi siswa dan menumbuhkan semangat belajar, sehingga siswa memperoleh prestasi belajar yang memuaskan. Diharapkan hasil penelitian ini dapat memberikan kegunaan untuk pembelajaran matematika.

Berdasarkan penelitian terdahulu, terdapat beberapa penelitian yang dilakukan mengenai penggunaan budaya dalam pembelajaran sebagai upaya peningkatan mutu pendidikan, pengintegrasian nilai budaya dalam pembelajaran matematika, pengembangan model-model pembelajaran dengan nilai budaya, serta mentransformasikan pembelajaran matematika melalui budaya (Abi, 2017; Rakhmawati, 2016; Ramadani, Praska, Christian, \& Dharma, 2014; Rohaeti, 2011; Wahyudin, 2018; Wahyuni et al., 2013). Dan terdapat penelitian yang membahas tentang tradisi meron dalam perspektif dakwah dan keagamaan (Atabik, 2020; Maisyanah, 2018; Maisyanah \& Inayati, 2019; Pramudyani, 2011; Rahmawati, Triyanto, \& Purwanto, 2019). Beberapa penelitian sebelumnya tersebut belum ada yang mendeskripsikan tentang aktivitas etnomatematika tradisi meron di Sukolilo Pati. Hal itu menjadi keunikan tersendiri dari penelitian ini yang memiliki tujuan untuk mengkaji etnomatematika tradisi meron di Sukolilo Pati.

\section{METODE PENELITIAN}

Jenis penelitian yang digunakan pada penelitian ini adalah penelitian eksploratif, penelitian yang dilakukan dengan menggali informasi untuk menemukan dan mengetahui suatu gejala atau permasalahan dengan adanya penjajakan terhadap masalah tersebut. Pendekatan yang dilakukan peneliti yaitu pendekatan etnografi yaitu 
pendekatan teoritis dan empiris yang bertujuan untuk mendeskripsikan dan menganalisis tentang suatu permasalahan tentang kebudayaan secara intensif (Moleong, 2017). Teknik analisis data yang digunakan peneliti adalah metode deskriptif kualitatif. Dalam penelitian ini, penggunaan metode tersebut dilakukan untuk mendapatkan deskripsi tentang adanya etnomatematika pada tradisi meron di Sukolilo, khususnya pada topik geometri, serta implementasinya dalam pembelajaran matematika.

Data dalam penelitian ini diperoleh melalui observasi, wawancara dengan beberapa tokoh atau warga masyarakat Sukolilo. Sumber dan jenis data dalam penelitian ini adalah foto meron, kata-kata hasil wawancara, dan sumber tertulis berupa buku, skripsi, dan arsip dari tradisi meron. Dalam penelitian ini terdapat 5 orang sebagai subjek penelitian yaitu warga desa Sukolilo Pati. Subjek penelitian dipilih melalui teknik purposive sampling.

Penelitian ini menggunakan prosedur penelitian Moleong (2017). Langkah-langkah penelitian yang dilakukan yaitu membuat instrumen penelitian berupa pedoman terkait tradisi meron di Sukolilo Pati. Kemudian instrumen divalidasi oleh ahli di bidang pendidikan matematika. Dilanjutkan dengan wawancara dengan narasumber dan observasi tradisi meron. Setelah itu, melakukan analisis semua data menurut Huberman dan Miles (2002) dengan langkah-langkah reduksi data, display data, dan menarik kesimpulan.

\section{HASIL PENELITIAN DAN PEMBAHASAN}

Terdapat beberapa prosesi acara dalam tradisi meron yang dilakukan secara berjenjang yaitu mulai persiapan acara, pelaksanaan acara dan pasca acara. Acara sakralnya yaitu terdapat pada prosesi pelaksanaan acara yang biasanya dilakukan adanya pemberangkatan meron yang diiringi dengan doa bersama. Dalam tradisi meron biasanya terdapat 14 meron yang diarak, hal tersebut melambangkan komitmen dari 13 desa, baik perangkat dan rakyatnya untuk senantiasa hidup rukun, damai, dan patuh terhadap agama. Berdasarkan wawancara dengan bapak Suharto, beliau menjelaskan bahwa tradisi meron ini menjunjung nilai persatuan, karena dalam tradisi meron ini diikuti oleh masyarakat dari 
segala umur meski tidak saling mengenal. Sejalan dengan semboyan bangsa Indonesia yaitu Bhineka Tunggal Ika, dan di dalam Islam juga diajarkan adanya silaturrahmi dan toleransi antar sesama.

Meron adalah sebuah acara arak-arakan yang berbentuk gunung yang diiring menuju masjid agung untuk dibacakan doa dan istigasah, kemudian dibagikan kepada masyarakat sekitar. Meron diibaratkan sebagai keinginan manusia supaya memperoleh keberhasilan yang diinginkan dan pencapaian tingkat kejayaan. Bentuk meron yang mengerucut dapat dilihat pada Gambar 1:

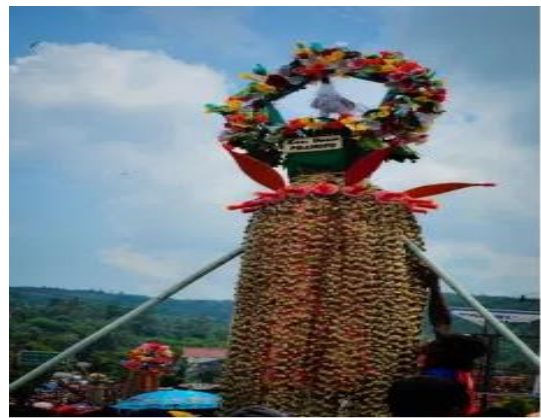

Gambar 1. Bentuk Meron

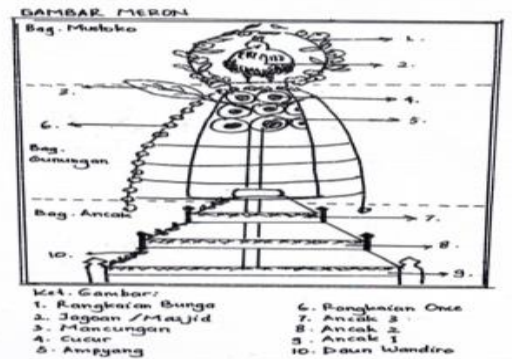

Gambar 2. Bagian-bagian Meron

Berdasarkan hasil penelitian yang dilakukan pada bulan November 2020, meron memiliki beberapa bagian yang memiliki makna berbedabeda tiap bagiannya, hal tersebut bisa dilihat pada Gambar 2. Bagianbagian meron meliputi mustaka, gununggan (nduwuran) (lihat Gambar 4), dan ancak. Pada bagian mustakaa, ini biasanya berbentuk replika ayam jago (untuk kepala desa) atau replika masjid (untuk modin). Dapat dilihat pada Gambar 3. Pada bentuk miniatur ayam jago tersebut memiliki makna bahwa seorang pemimpin harus bisa menjadi teladan bagi masyarakat sehingga menjadikan harum nama desanya. Dan ayam jago tersebut melambangkan arti keperwiraan dan keberanian. Sedangkan bentuk masjid tersebut memiliki makna masyarakat harus selalu beribadah dan ingat kepada tuhan YME. Bentuk masjid tersebut melambangkan nilai-nilai keislaman dan lambang ketaatan kepada Allah SWT (Hasyim, 2011). Pada bagian mustaka tersebut dikelilingi karangan 
bunga. Karangan bunga tersebut memiliki makna tersendiri yaitu adanya keikhlasan dalam beramal dan saling menjaga kesatuan dan persatuan bangsa. Karangan bunga kertas tersebut berbentuk lingkaran dengan diameter $60 \mathrm{~cm}$.
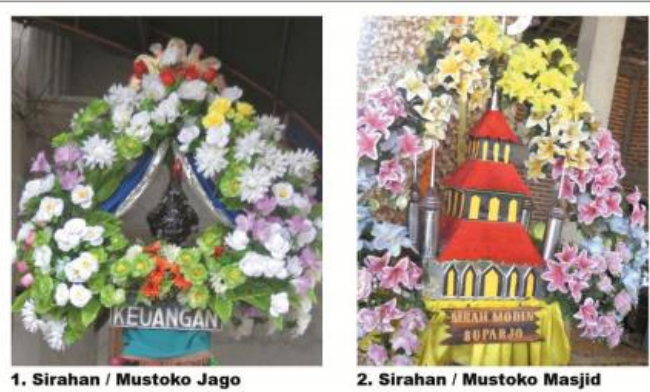

Gambar 3. Bagian Mustaka Meron

Bagian kedua yaitu gunungan (nduwuran) ini terdiri dari ampyang, mancungan, cucur, dan once. Bagian-bagian tersebut memiliki makna tersendiri yaitu amyang diibaratkan sebagai benteng atau perisai dari kajahatan, mancungan dilambangkan sebagai tumbak kekuatan manusia, cucur melambngkan semangat dan tekad masyrakat Sukolilo, dan once yang melambangkan keikhlasan beramal demi menciptakan kerukunan dan persatuan antar masyarakat. Bagian ketiga yaitu ancak (lihat Gambar 5). Ancak dalam meron ini ada tiga tingkatan dan masing-masing memiliki makna filosofis tersendiri. Menurut (Atabik, 2020) ketiga tingkatan ancak pada meron tersebut melambangkan Islam, iman dan ihsan yang diajarkan Nabi Muhammad SAW.

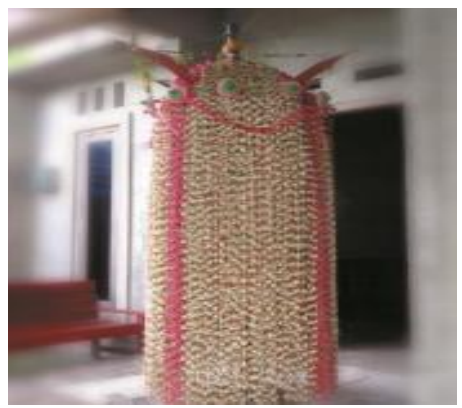

Gambar 2. Bagian Gunungan Meron 


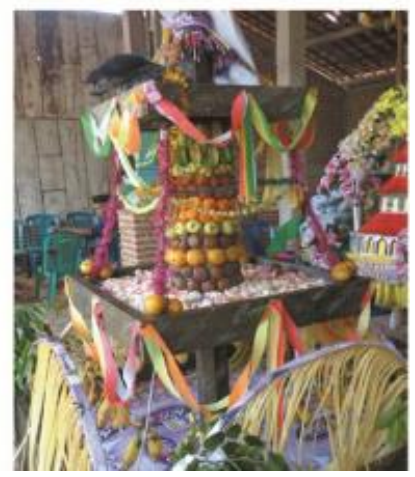

\section{Gambar 3. Bagian Ancak Meron}

Dari penjelasan di atas, relevansi bagian-bagian meron dalam materi matematika khususnya materi geometri adalah pertama, pada bagian mustaka tersebut terdapat kerangka bunga yang berbentuk lingkaran yang mengelilingi miniatur jago atau masjid tersebut dengan diameter $60 \mathrm{~cm}$. Hal tersebut dapat digunakan guru dalam pembelajaran matematika dengan meminta siswa untuk mencari luas dari bagian karangan bunga tersebut. Siswa dapat belajar mengenai keliling bangun datar lingkaran melalui pengamatan pada bagian mustaka tersebut. Siswa sudah mengetahui terlebih dahulu bahwa keliling bangun datar lingkaran yaitu $\pi \times d$ atau $\pi \times 2 \times r$.

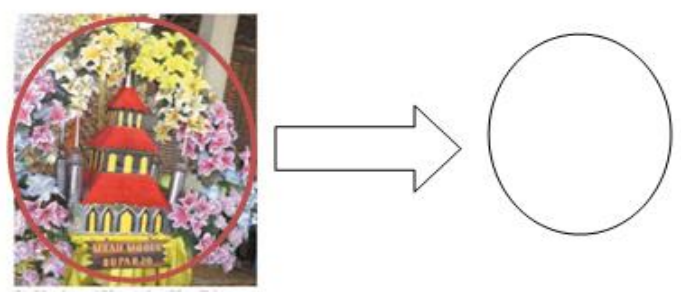

\section{Gambar 4. Bagian Mustaka Meron}

Pada Gambar 7 tersebut dapat diamati bahwa mustaka yang berbentuk masjid itu jika di mengandung bentuk bangun ruang kubus dan limat segiempat. Agar hasil pembuatannya masksimal tentunya dalam membuat miniatur masjid tersebut harus mengetahui volume dari kedua bangun tersebut terlebih dahulu. 

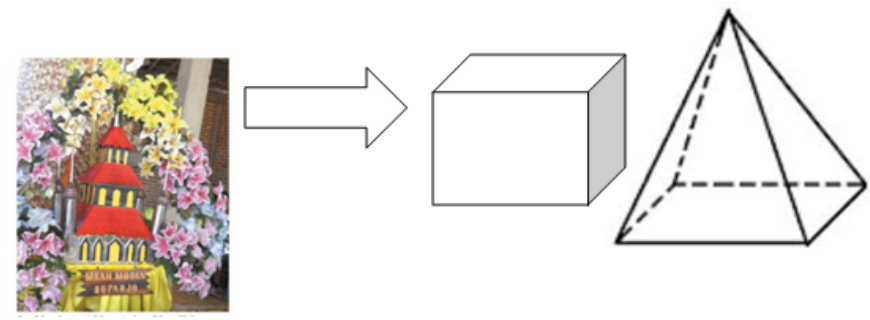

\section{Gambar 5. Bagian Mustaka bentuk Masjid}

Kedua, pada bagian gunungan tersebut berbentuk bangun datar kerucut. Bagian gunungan tersebut akan di kelilingi oleh once. Once ini biasanya berupa nasi yang dikepal dan dibentuk menyerupai bentuk lingkaran. Berdasarkan hal tersebut, guru dapat meminta siswa untuk menghitung berapa banyak once yang perlu dipasang pada gunungan dengan menghitung luas selimut bangun kerucut tersebut terlebih dahulu. Siswa harus mengetahui rumus luas selimut bangun datar kerucut yaitu nrs dengan $\mathrm{s}$ adalah panjang garis pelukis kerucut.

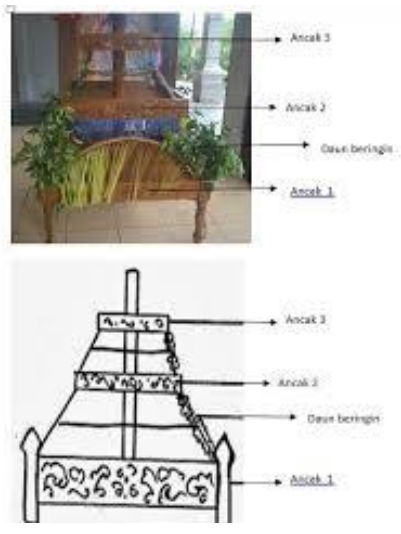

\section{Gambar 6. Bagian Ancak Meron}

Ketiga, bagian ancak jika di amati pada Gambar 8 terdapat dua bangun datar yaitu persegi panjang dan trapesium. Pada pembuatan ancak juga terdapat pembelajaran tentang perbandingan di mana perbandingan antara ancak 1 dengan ancak 2 dengan ancak 3 itu berbeda-beda. Perbandingannya yaitu semisal ancak 1: ancak 2: ancak $3=3: 2: 1$. Tentunya dalam proses pembuatan ancak tersebut juga harus 
memperhatikan perbandingan ukuran dengan tepat supaya hasil pembuatan yang diperoleh bisa estetik.

Implementasi tradisi meron yang dapat dilakukan dalam pembelajaran matematika dapat dilihat pada Tabel 1 .

\section{Tabel 1. Implementasi Tradisi Meron pada Pembelajaran Geometri}

\begin{tabular}{|c|c|}
\hline Kegiatan & Penjelasan \\
\hline Pembukaan & $\begin{array}{l}\text { 1. Guru memaparkan sasaran pembelajaran } \\
\text { yang diinginkan, dan mengaitkannya dengan } \\
\text { budaya seperti tradisi meron, khususnya } \\
\text { pada gunungan yang diarak pada puncak } \\
\text { acara meron. } \\
\text { 2. Siswa dapat memperhatikan dan mengamati } \\
\text { gambar-gambar gunungan yang ada pada } \\
\text { tradisi meron. }\end{array}$ \\
\hline Inti & $\begin{array}{l}\text { 1. Guru menjelaskan materi bangun ruang } \\
\text { dengan menghubungkannya dengan bentuk } \\
\text { gunungan pada tradisi meron. } \\
\text { 2. Guru dapat membentuk kelompok- } \\
\text { kelompok dari jumlah siswa dengan } \\
\text { ketentuan 3-4 orang per kelompok. } \\
\text { 3. Guru memerintahkan masing-masing } \\
\text { kelompok untuk mengamati gunungan, } \\
\text { kemudian masing-masing kelompok } \\
\text { melakukan identifikasi mengenai bangun } \\
\text { ruang apa yang sama dengan bentuk } \\
\text { gunungan pada tradisi meron. } \\
\text { 4. Setiap kelompok berdiskusi dengan anggota } \\
\text { kelompoknya. } \\
\text { 5. Perwakilan anggota } \\
\text { mempresentasikan hasil diskusi di depan } \\
\text { kelas. }\end{array}$ \\
\hline Penutup & $\begin{array}{l}\text { 1. Guru dapat memilihi secara acak satu siswa } \\
\text { untuk memberikan kesimpulan atas } \\
\text { penjelasan presentasi } \\
\text { 2. Guru mengomentari dan menambahi } \\
\text { penjelasan mengenai hasil diskusi }\end{array}$ \\
\hline
\end{tabular}


Tabel 1. menunjukkan bahwa model pembelajaran yang digunakan guru adalah model pembelajaran kooperatif. Dengan guru membagi siswa secara berkelompok-kelompok, sehingga siswa aktif dalam pembelajaran mulai mengamati, berdiskusi, dan mempresentasikan hasil diskusi. Guru dapat membuat soal mengenai meron tersebut yaitu: "Pak Hendro membuat bagian gunungan meron seperti Gambar 9 dengan tinggi $105 \mathrm{~cm}$ dan diameter alasnya $176 \mathrm{~cm}$. Rencananya gunungan tersebut akan dihiasi dengan once yang berdiameter $3 \mathrm{~cm}$. Berapa banyak once yang dibutuhkan pak Hendro untuk menghias gunungan tersebut?"

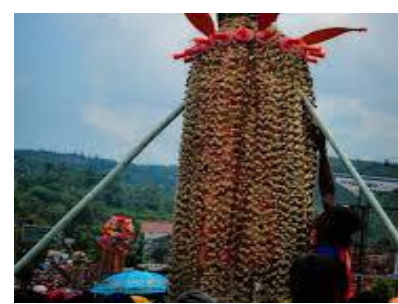

Gambar 7. Gunungan Meron

\section{SIMPULAN}

Etnomatematika pada tradisi meron ini dapat dilihat pada masingmasing bagian meron. Pada bagian mustaka terdapat karangan bunga yang berbentuk bangun datar lingkaran dan pada bentuk miniatur masjid terdapat bentuk bangun ruang kubus dan limas segiempat, bagian gunungan terdapat bentuk kerucut, bagian ancak terdapat dua bangun datar yaitu persegi panjang dan trapesium. Siswa juga bisa mencari keliling dari unsur bangun datar yang ada pada meron dan volume dari bagian-bagian meron tersebut, seperti dalam pembuatan karangan bunga tersebut harus mengetahui keliling lingkaran karangan bunga tersebut terlebih dahulu. Pembuatan miniatur masjid juga membutuhkan pengetahuan tentang perbandingan.

\section{DAFTAR PUSTAKA}

Abi, A. M. (2017). Integrasi Etnomatematika dalam Kurikulum Matematika Sekolah. JPMI (Jurnal Pendidikan Matematika Indonesia), 1(1), 1. https://doi.org/10.26737/jpmi.v1i1.75 
Atabik, A. (2020). Interaksionisme Simbolik Ritual Meron di Indonesia dan Relevansinya dalam al Quran. Fikrah, 8(1), 137. https://doi.org/10.21043/fikrah.v8i1.7216

Auliya, N. N. F. (2019). Etnomatematika Kaligrafi Sebagai Sumber Belajar Matematika Di Madrasah Ibtidaiyah. Jurnal Pendidikan Matematika (Kudus), 1(2). https://doi.org/10.21043/jpm.v1i2.4879

Crato, N. (2020). Improving a Country 's Education. https://doi.org/https://doi.org/10.1007/978-3-030-59031-4

D'Ambrosio, U. (1985). Ethnomathematics and Its Place in the History and Pedagogy of Mathematics. For the Learning of Mathematics, 5(1), 4448. Retrieved April 29, 2021, from http://www.jstor.org/stable/40247876 Fahrida, N. (2012). Aspek Pendidikan Nilai Religius dalam Pelaksanaan Tradisi Meron (Studi Kasus di desa Sukolilo Kecamatan Sukolilo Kabupaten Pati).

Hasyim, M. (2011). Penelitian Makna Arsitektur Masjid Pakualaman Dalam Tinjauan Kosmologi Jawa. Analisa, XVIII(02), 211-227.

Huberman, M., \& Miles, M. B. (2002). The qualitative researcher's companion. Sage.

Maisyanah. (2018). Internalisasi Nilai-nilai Pendidikan Agama Islam pada Tradisi Meron. Edukasia Jurnal Penelitian Pendidikan Islam.

Maisyanah, M., \& Inayati, L. (2019). Internalisasi Nilai Pendidikan Agama Islam pada Tradisi Meron. Edukasia: Jurnal Penelitian Pendidikan Islam. https://doi.org/10.21043/edukasia.v13i2.4627

Makhmudah, S. (2018). Analisis Literasi Matematika terhadap Kemampuan Berpikir Kritis Matematika dan Pendidikan Karakter Mandiri. Prisma, 1, 318-325.

Moleong, L. J. (2017). Metodologi Penelitian Kualitatif (Edisi Revisi). PT. Remaja Rosda Karya.

Nur, R., Hobri, \& Dian. (2015). Eksplorasi Etnomatematika Masyarakat Suku Madura di Situbondo. Artikel Ilmiah Mahasiswa, II(1), 1-4.

OECD. (2019). PISA 2018 Results (Volume I). https://doi.org/10.1787/5f07c754-en 
Pramudyani, F. N. H. (2011). Upacara Tradisi Meron Relevansinya Dengan Kehidupan Masyarakat Desa Sukolilo Kabupaten Pati. $J P P 1(2)$.

Prasetyawan, D. G. (2016). Diagnosis Kesulitan Belajar Matematika Siswa Kelas IV SD Negeri Congkrang 1 Muntilan Magelang. Basic Education, 5(26), 2481-2488.

Rahimah, N., \& Asy'ari, A. (2017). Keterampilan Dasar Geometri Siswa Kelas V dalam Menyelesaikan Soal Bangun Datar Berdasarkan Kemampuan Matematika Di MI Al Istiqomah Banjarmasin. Math Didactic, 3(1), 55-63. https://doi.org/10.33654/math.v3i1.55

Rahmawati, D. ., Triyanto, \& Purwanto. (2019). Meron sebagai Karya Seni Rupa: Kajian Nilai Estetik dan Fungsinya dalam Tradisi Perayaan Maulid Nabi di Desa Sukolilo Pati. Journal of Arts Education.

Rakhmawati, R. (2016). Aktivitas Matematika Berbasis Budaya pada Masyarakat Lampung. Al-Jabar: Jurnal Pendidikan Matematika, 7(2), 221-230.

Ramadani, Y. A., Praska, M., Christian, T. F., \& Dharma, U. S. (2014).

Aktivitas Designing Serta Implementasinya dalam Pembelajaran. 241-246.

Rohaeti, E. E. (2011). Transformasi Budaya Melalui Pembelajaran Matematika Bermakna di Sekolah. Jurnal Pengajaran Matematika dan Ilmu Pengetahuan Alam, 16(1), 139. https://doi.org/10.18269/jpmipa.v16i1.274

Wahyudin. (2018). Etnomatematika dan Pendidikan Matematika Multikultural. Prosiding Seminar Nasional Pendidikan Matematika Etnomatnesia, 1-19.

Wahyuni, A., Aji, A., Tias, W., \& Sani, B. (2013). Peran Etnomatematika dalam Membangun Karakter Bangsa: Penguatan Peran Matematika dan Pendidikan Matematika untuk Indonesia yang Lebih Baik. 